DOI: https://doi.org/10.34069/AI/2021.46.10.11

How to Cite:

Husieva, V., Lukash, S., Krykun, V., Morhunov, O., \& Shapoval, K. (2021). Conditions conducive to the domestic violence against the elderly based on the judicial and investigative practice of Ukraine. Amazonia Investiga, 10(46), 118-127. https://doi.org/10.34069/AI/2021.46.10.11

\title{
Conditions conducive to the domestic violence against the elderly based on the judicial and investigative practice of Ukraine
}

\section{Умови, що сприяють домашньому насильству щодо осіб похилого віку на основі судово-слідчої практики України}

Received: September 10, 2021

\begin{abstract}
The purpose of the article is to identify the causes and conditions that contribute to the commission of domestic violence against the elderly, as well as the possible consequences of this phenomenon. The article dedicated to exploring the facts of abuse of family members to the elderly. The authors use general and special methods that allow obtaining scientifically based conclusions and suggestions, such as analys, comparison, classification, grouping method, dialectical and forecasting method. In particular, the practice of law enforcement agencies of Ukraine was analyzed and it was established that murders can be the ultimate negative consequence of domestic violence. It was determined that different criteria are used in determining the age category of the elderly in different countries, and therefore, the authors took as a basis the category of women over 55 and men over 60 . In this study, the terms "elderly person" and "old people" are used
\end{abstract}

Accepted: October 20, 2021
Анотація

Боротьба 3 домашнім насильством є досить актуальним завданням правоохоронних органів України та зарубіжних країн. Метою статті $\epsilon$ виявлення причин та умов, що сприяють вчиненню домашнього насильства щодо осіб похилого віку, а також можливих наслідків даного явища. Стаття присвячена дослідженню фактів жорстокого поводження з боку членів сім'ї до осіб похилого віку. Зокрема, проаналізовано практику правоохоронних органів України та встановлено, що вбивства можуть бути кінцевим негативним наслідком вчинення насильства в сім'ї. Визначено, що під час визначення вікової категорії осіб похилого віку в різних країнах застосовуються різні критерії, у зв'язку з чим, авторами за основу було взято категорію жінок, віком від 55 років і чоловіків віком понад 60 років. У зазначеному дослідженні поняття «особа похилого віку» та «літні люди» вживаються

\footnotetext{
${ }^{35}$ Professor of the Department of Criminalistics, Forensic Science and Pre-medical care of Faculty №1 of Kharkiv National University of Internal Affairs, Dc Sc in Law, Associate Professor, Kharkiv, Ukraine.

${ }^{36}$ Head of Sumy Branch of Kharkiv National University of Internal Affairs, Honored Lawyer of Ukraine, Dc Sc in Law, Professor, Honored Lawyer of Ukraine, Kharkiv, Ukraine.

${ }^{37}$ Professor of the Department of Law-Enforcement Activity and Policeistics of Faculty №6 of Kharkiv National University of Internal Affairs, Dc Sc in Law, Associate Professor, Kharkiv, Ukraine.

${ }^{38}$ Professor of the Department of Law-Enforcement Activity and Policeistics of Faculty №6 of Kharkiv National University of Internal Affairs, Dc Sc in Law, Associate Professor, Kharkiv, Ukraine.

${ }^{39}$ Adjunct of the Department of the Organization Educational and Scientific Training of Kharkiv National University of Internal Affairs, Kharkiv, Ukraine.
} 


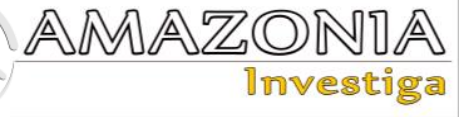

interchangeably. The analysis of the legislation of foreign countries allowed to single out the problematic issues of legal qualification of the facts of domestic violence committed against the elderly, as well as the reasons and conditions that contribute to its commission.

Key words: elderly person, domestic violence, murder.

\section{Introduction}

In the contemporary world, the problem of domestic violence, despite all the achievements of the civilization, remains relevant. Such violence remains one of the most common forms of human rights violations, mainly affecting the most vulnerable groups (children, women who are economically, psychologically or otherwise dependent on men, intimate partners or parents, people with disabilities, the elderly and etc.). This is due to the inability to defend themselves, less physical strength, fear of revenge, lack of protection, shelter, and so on.

The problem of domestic violence has been closely hidden by the prohibition of state interference in the private lives of individuals for a long time. The modern legal doctrine, international law and the Heritage European Convention, concentrated in the case law of the European Court of Human Rights, have clearly taken the position that the fundamental rights of everyone are the inalienable right to life, liberty and security of person, respect for their honor and dignity, and the prohibition of torture, forced labor and discrimination is the basis of the legal status of man in a civilized society. This means that everyone, regardless of gender, age, health or any other factor, has the right to effective protection against all forms and manifestations of violence, and protection against violence committed by family members or other relatives, should be not less than from the commission of violent acts by outsiders (Evsyukova, Hristova, \& Shapovalova, 2011, p. 6). як синоніми. Визначено, що в Україні питання попередження, розслідування та протидії насильству в сім’і врегульовані Законом України «Про запобігання та протидію домашньому насильству», адміністративним законодавством, а дії, що мають більш тяжкі наслідки регулюються кримінальним законодавством України. Аналіз законодавства зарубіжних країн дозволив виокремити проблемні питання правової кваліфікації фактів домашнього насильства, вчинених відносно осіб похилого віку, а також причини й умови, що сприяють його вчиненню. Обгрунтовано необхідність вжиття заходів для забезпечення профілактики та попередження фактів домашнього насильства щодо осіб похилого віку.

Ключові слова: особа похилого віку, домашнє насильство, вбивство.

The Law of Ukraine "On Prevention and Counteraction to Domestic Violence" defines the range of persons to whom it applies. In particular, it guarantees the rights of the elderly. The facts of domestic violence involving the elderly most often occur between adult children and parents. Violence can be perpetrated by both adult children and their parents, although the former is the most common. It is quite typical for children who grew up in an atmosphere of violence to establish their relationship with their parents on the same basis of violence. Violence against parents can also occur in families where children have grown up in an atmosphere of permissiveness.

The problem of domestic violence against the elderly has been exciting for a long time. Karl Pillemer and David Finkelhor (1988) emphasized this in 1988, noting that abuse of the elderly is a form of domestic violence. The scientists have stated the fact of latency of this problem, because family problems are not publicly available. The latter also pointed out that there were cases of abuse of elderly people during their care and cohabitation with other persons.

This issue is quite relevant for Ukraine as well. In particular, G. Gerasimenko (2018, p. 48) notes that in Ukraine the problem of intergenerational domestic violence is quite acute, as every ninth respondent appealed to the police about violence by their own children or grandchildren. This category of victims is mostly the elderly: half of 
the respondents who experienced violence from children belonged to the age group over 60 years. Their appeals are also mostly related to physical violence; emotional violence was the cause of appealing in only a third of cases.

A separate problem during the investigation of criminal offenses, as well as the consideration of administrative offenses should be given to the psychiatric condition of the elderly. Thus, Acierno (2003, p. 265) stated that among the elderly who are cognitively impaired, abuse or violence is conceptually similar to domestic violence in its etiology, whereas among the cognitively impaired elderly, abuse is conceptually similar to violence against children. That is, the elderly who have mental illness are an even more vulnerable category of the population and may not be aware of the illegality of actions taken against them.

The elderly remain the least protected part of the population. This highlights the need to take appropriate measures to ensure the protection of the rights of victims of domestic violence. Achieving this goal is possible by identifying the causes and conditions that contribute to the commission of domestic violence against the elderly.

\section{Legal framework}

The study is based on domestic legislation of Ukraine. In particular, the Criminal Code of Ukraine (Law No. 2341-III, 2001), the Law of Ukraine "On Compulsory State Pension Insurance" (Law No. 1058-IV, 2003), the Law of Ukraine "On Prevention and Counteraction to Domestic Violence" (Law No. 2229-VIII, 2017), Law of Ukraine "On Basic Principles of Social Protection of Labor Veterans and Other Elderly Citizens in Ukraine" (Law No. 3721-XII, 1993). The provision and the necessity for ratification of an international document was analyzed, namely the Council of Europe Convention on Preventing and Combating Violence against Women and Domestic Violence (Liga 360, 2011).

In addition, the publications of domestic and foreign scholars on the study of domestic violence with the participation of the elderly were analyzed. The analysis of the international experience of struggle against these phenomena is carried out.

\section{Methodology}

The method of analysis was applied to scientific articles that were identified using electronic search strategies on various search platforms of databases.

Methods of analysis and comparison were used in the study of domestic violence in Ukraine and the practice of foreign countries, as well as Ukrainian and international law.

The classification and grouping methods were used to determine the causes and forms of domestic violence.

The dialectical method reveals the general properties, connections and patterns of behavior of people in the family where the elderly live.

The forecasting method is used to introduce measures that can reduce the level of domestic violence against the elderly.

\section{Results and discussion}

The study of the causes and conditions that contribute to the commission of domestic violence against the elderly first of all requires the definition of the question of what category of persons should be understood by the term elderly person. According to the current legislation of Ukraine, elderly people are persons who have reached the retirement age established by Article 26 of the Law of Ukraine "On Compulsory State Pension Insurance", as well as persons who have no more than one and a half years left to reach the specified retirement age. The pensioners in Ukraine are considered to be men under the age of 60 , women under the age of 55, but entitled to various state pensions (for example, servicemen). The World Health Organization includes to the old peopled the population aged 60 to 74 , the elderly aged 75 to 89 , and the long-lived 90 years and older (Morgay, 2018, p. 159). Thus, to achieve the goal of this study, we selected a group of elderly people, which included men aged 60 years and women aged 55 years.

Domestic violence against the elderly can take many forms. In particular, cover psychological, physical, economic and, less frequently, sexual. Thus, domestic violence against the elderly is manifested in both action and inaction, namely: bodily injury, improper care, swearing, failure to provide assistance, blocking contacts, restricting communication, and so on. A more detailed classification of manifestations of domestic violence indicates that not only the types of violence provided by law can be applied to the elderly, namely: 


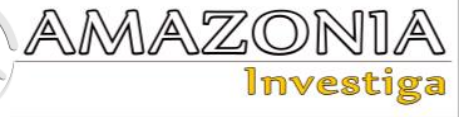

- physical violence: causing physical pain, injury, or even murder, forcible coercion to something, as well as the introduction of various types of prohibitions against the elderly, restrictions on his rights and freedoms;

- sexual violence: any type of harassment, expressed in the form of imposed sexual abuse, sexual humiliation and rape;

- medical violence: negligence and lateness in the issuance of drugs, intentional overdose of the drug or, conversely, the refusal to patient to receive the necessary drugs;

- neglect: irresponsibility and failure of the guardian to perform his duties in relation to the elderly, resulting in various injuries and violations of his rights;

- passive contempt for the elderly: isolation, leaving the person alone or ignoring his existence. Active neglect of the elderly can occur when a person is deliberately deprived of things necessary for normal existence (food, medicine, bathing, communication, etc.) or when a physically dependent person is not provided with adequate care and attention;

- $\quad$ psychological (emotional) violence: causing a person mental suffering, swearing and insulting to her, threats, as well as the formation and development of her feelings of fear;

- economic violence: is expressed in the form of appropriation by other family members of property or funds of an elderly person without his consent, illegal or carried out against the person's desire to use his savings (Kholostova, 2009, p. 17; Volodina, Malinovskaya, 2020, p. 83). The above types of violence fall under the Law of Ukraine "On Prevention and Counteraction to Domestic Violence", administrative legislation, and actions that have more serious consequences - the criminal legislation of Ukraine. We believe that this list should be supplemented by cruel treatment of the elderly.

Having identified the types of violence, we propose to analyze more detailed the features of domestic violence with the participation of the elderly. Abusive treatment of the elderly is the commission of any one-time or periodic acts or the absence of appropriate actions where a relationship of trust is presumed, which harms or causes stress to the elderly (aged 60 or over). This type of violence includes leaving without care, negligence as well as impairment of dignity and disrespect. Manifestations of this type of violence can be observed both among the population, as well as by representatives of state and commercial institutions, enterprises and organizations.

The problem of domestic violence against the elderly is also relevant given that the population of most Member States in the WHO European Region is aging: in 2050, a third of the population reach the age of 60 or older, and therefore a much larger number of people will be exposed to the risk of abuse treatment:

- more than 5500 elderly people are murdered each year;

- $\quad$ in the Region it is reported that more than 30 million elderly people (one in six) being abused during the previous year;

- the prevalence of the elderly abuse is higher among women, the older adults and people with cognitive impairments, disabilities, high dependence on others and the need for support;

- The prevalence of abuse of the elderly in group homes is higher than at home (Quigg, Butler, Passmore, Yon, \& Nihlén, 2020).

According to the Council of Europe Convention on Preventing and Combating Violence against Women and Domestic Violence, domestic violence against the elderly is hidden. At the same time, published statistics show that the number of victims of domestic violence is quite significant. According to research by Czech public organizations, about $10 \%$ of the elderly people experience domestic violence, and statistics in Belarus show that $20 \%$ of women over the age of 60 suffer from domestic violence. Such small data (only the Czech Republic and Belarus), to some extent, confirms the lack of complete official statistics on the use of violence against the elderly in various European countries and Ukraine in particular (Lysenko, 2017, p. 281).

A large-scale sample survey of the elderly abuse and neglect in 2020 in the Boston area interviewed older people living in communities about their experiences of physical violence, verbal aggression, and neglect. The overall level of abuse treatment was 32 elderly people per 1000 people. It has been found that the most likely offenders are spouses, and approximately equal numbers of men and women are victims of violence, although women suffer from more serious abuse. The potential respondents were randomly selected from the individuals on the list who were 65 years of age or older. Overall, $65 \%$ of the sample were women; $94 \%$ were white; $60 \%$ of the sample were aged $65-74$ and $40 \%$ 
over 75; 58\% were Catholics, 30\% Protestants, $8 \%$ Jews and $4 \%$ others; $38 \%$ had family incomes in excess of 15000 USD per year and $62 \%$ had incomes below 15000 USD; $40 \%$ lived alone, $37 \%$ with a spouse, $5 \%$ only with a child, $10 \%$ with a spouse and someone else (usually a child), and $7 \%$ with others (Pillemer, \& Finkelhor, 1988).

According to the results of a survey conducted in the United States (5777 respondents), it was found that domestic violence against the elderly was distributed as follows: $4.6 \%$ belongs to the emotional violence, $1.6 \%$ to the physical violence, $0.6 \%$ to the sexual violence, $5.1 \%$ is neglect and $5.2 \%$ is financial abuse by a family member. The most consistent correlates of abuse among different types of abuse were low social support and previous exposure to traumatic events (Acierno, Hernandez, \& Ananda, 2009).

Based on these statistics, we conclude that abuse of the elderly is widespread. The most common form of domestic violence in the United States against the elderly is psychological and economic violence. The development of social support through preventive measures can help solve this problem. In particular, studying the relationship between abuse and the health of the older people, researchers emphasize the necessity to detect sensitivity on the part of physicians and other medical staff to the possibility of detecting and preventing abuse of their patients (Laumann, Leitsch, \& Waite, 2008).

Therefore, the most vulnerable category of people from domestic violence are the elderly. The task of each state is to develop and take effective measures to warn, investigate and prevent this offense.

The particular attention should be paid to the fact that domestic violence can result in murder. In the investigative and judicial practice of Ukraine and other countries (Homer, \& Gilleard, 1990) there are cases when people who cared for victims (the elderly) due to emotional exhaustion, alcohol abuse and long-term hostility committed the murder of the latter. The victims of this crime are the dead, but the subjects of the crime are those who have been systematically subjected to domestic violence. Therefore, an example of a murder committed in connection with the use of domestic violence in Ukraine is the criminal proceedings entered in the Unified Register of Pre-trial Investigations under No.20112016040540000580 dated September 30, 2016 under Article 116 of the Criminal Code of Ukraine. During the pre-trial investigation, it was established that the suspect was caring for an 82-year-old victim. The latter constantly terrorized the suspect and committed psychological (emotional) violence against her. The behavior of the victim provoked the suspect, who as a result of emotional exhaustion committed murder, namely: killed the elderly person (Case no. 388/147/14-к).

Similar to the previous example is the criminal proceedings No. 12013120050001165 under Article 116 of the Criminal Code of Ukraine, where a retired father killed the son-offender who committed illegal violence, used physical violence, systematically abused, etc. (Case no. 189/1805/16-к).

The examples given are not unique. According to the results of our analysis, it is established that the facts of domestic violence that preceded the commission of other crimes in practice are not given enough attention. Such crimes are investigated on the basis of the end result. Based on the above, we consider it necessary to propose amendments to the criminal legislation of Ukraine, namely: to supplement Section II of the Special Part of the Criminal Code of Ukraine with an article criminalizing murder in connection with the use of domestic violence.

Having analyzed the scale of domestic violence against the elderly, as well as identifying the socially dangerous consequences of these acts, we propose to analyze domestic and international experience in counteracting violence.

The Law of Ukraine "On Prevention and Counteraction to Domestic Violence", which amended the Code of Ukraine on Administrative Offenses, is currently in force in Ukraine. The number of appeals has significantly increased after the adoption of the law: in $2017-92.1$ thousand, in 2018 - 115.5 thousand. In early 2019, domestic violence was criminalized, namely the Criminal Code of Ukraine was amended by Article 126-1 "Domestic Violence". Kateryna Miteva, a spokeswoman for Amnesty International Ukraine, said that the amendments to the Criminal and Criminal Procedure Codes although introduced criminal liability for domestic violence by a family member or a loved one, but only if it was carried out "systematically" and repeatedly documented by the police as the administrative offense. That is, if a person has been abused and called the police, it is recorded for the first time as an administrative offense. In order to eradicate this practice, Ukraine needs to ratify the Council of 


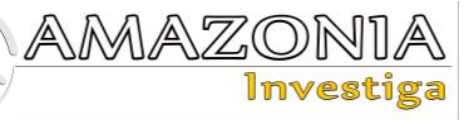

Europe Convention on Preventing and Combating Violence against Women and Domestic Violence (Istanbul Convention). After the ratification of the Convention, this should be changed (Minich, 2020).

It should be emphasized that the Istanbul Convention provides for raising awareness of the public, law enforcement agencies, courts, and lawyers in order to develop skills in recognizing victims of domestic violence and ensuring their proper protection. At the same time, it provides for classes for children in schools, where they should be taught the principles of equality between women and men and the prevention of violence (Movchan, Neledva, Kalimbet, Medentsev \& Nikitina-Dudikova, 2021). It also provides for the implementation of external control, which involves maintaining statistical records of information. The implementation of international legislation and experience in overcoming and combating domestic violence, especially of vulnerable groups, can contribute to the application and formation of a legal framework for the development and improvement of domestic law and law enforcement practices in the field of domestic violence prevention.

Not Ukraine's ratification of this convention leads to the fact that the analysis of cases of domestic violence in Ukraine against the elderly is not carried out properly. In particular, statistical reports indicate only the total number of crimes committed against the elderly (pensioners). This leads to an incorrect assessment of the problems associated with this phenomenon, as well as the inability to ensure a proper response to such facts.

In addition, the non-introduction of international experience into the investigative and judicial practice of Ukraine leads to problems of legal assessment of committed acts. The consequences of committing domestic violence in practice are qualified under the relevant article of the Criminal Code of Ukraine without specifying the signs of domestic violence. The same is true in France and Germany, where crimes committed in connection with domestic violence are classified as violent crimes in general. But, both in France and in Ukraine, the commission of violence against a spouse and partner is an aggravating punishment for all crimes (Mytnyk, 2019, p. 86). Domestic legislation also contains a provision that aggravates the punishment for committing a criminal offense against an elderly person, a person with a disability or a person who is helpless, or a person suffering from a mental disorder, including dementia, has a mental disability, as well as the commission of a criminal offense against a minor child or in the presence of a child. This rule should be applied during the consideration by courts of both the facts of domestic violence and the crimes that result from it, such as murder. Attention should also be paid to Belgian law, where domestic violence is classified as a criminal offense. Domestic violence is now considered as an aggravating circumstance, leading to more severe punishment. Therefore, this rule applies to married and unmarried couples and any other persons who maintain or have maintained a longterm emotional and sexual relationship with the victim. The country also has a Belgian National Action Plan against Violence, which covers domestic and other forms of violence (Lehenka, 2017, p. 114).

At the same time, analyzing the international experience of combating violence, it is necessary to highlight the policy of Germany. In the law enforcement practice of this country, there are five types of domestic violence, namely: physical, economic, psychological, sexual and social (Halai, Halai, Holovko, \& Muranova, 2014, pp. 52-54). In addition, Germany has a Federal Ministry of Family Affairs, Senior Citizens, Women and Youth, and the law details the types of violence, one of which is violence against the elderly in the family. In order to achieve the goals of the state policy on protection of victims, there are women's shelters, counseling centers, and centers for assistance to victims of domestic violence. As a result of a comparison of German and Ukrainian legislation, it was found that there is no social violence in Ukraine, which, although similar to psychological violence, is different.

The French legislation stated the following types of violence: physical, sexual, psychological, economic (Halai, Halai, Holovko, \& Muranova, 2014, pp. 66-73), which corresponds to the legally established types of violence in Ukraine. At the same time, in France, the interaction of police units with the "mobile hotline" is effectively established, which allows you to quickly arrive at the scene of domestic violence. In order to effectively combat violence, an interactive map of France with data from public service organizations on protection against violence has been created. In addition, police units have the right to immediately remove perpetrators of domestic violence from the place of residence with the victim, and the court may order such a measure to combat domestic violence as the use of electronic bracelets. With 
these bracelets, the police receive a signal that the perpetrator of domestic violence is approaching the victim, so the police can respond immediately. It is also possible to stay in shelters.

Analyzing the circumstances that provoke the increase in domestic violence, it is necessary to emphasize the position of Maria Gabriel, the EU Commissioner, who explains this by the outbreak of the epidemic caused by COVID-19. It is with the onset of this epidemic that there has been an increase in reports of domestic violence (OMS, 2020).

Circumstances that can provoke domestic violence, which in turn can lead to murder, also include a high level of abuse by the elderly in their care, which is especially associated with alcohol abuse and hostile relations with guardians (Homer, \& Gilleard, 1990). The rapid aging of the nation, which is taking place in most countries of the world, as well as the mental health problems of the elderly, are also causing an increase in domestic violence against the elderly.

We should also pay attention to the position by Serebryakova T., Koneva I., Ladykova O., Begantsova I., Kostina O., Yegorova T., \& Fomina, N. (2019) on the issue of manipulation used by children in contact with their parents. Undoubtedly, the manipulation used by children can be seen as a private form of violence of children against their parents. And the most amazing thing is that many parents do not understand (or do not want to understand) that manipulation is violence, use this form of interaction with their relatives and friends, thus giving a negative example of communication with others around their children.

Thus, there are many problems in connection with the prosecution of persons for domestic violence, due to the imperfection of current legislation, the difficulty of proving the guilt of perpetrators of domestic violence, the lack of awareness of investigators and judges themselves of the causes and consequences of such violence, the nature of the relationship between victims and offenders, their understanding of the significance of the problem in general and the practical skills of its identification.

In the course of the analysis of the scientific literature, it became possible to establish the reasons leading to the commission of domestic violence, namely:
- social (tensions, conflicts, violence in society; promotion of violence in the media as a model of behavior);

- economic (material deprivation; lack of decent living conditions and at the same time - lack of conditions for employment and earning money; economic dependence; unemployment);

- $\quad$ psychological (stereotypes of behavior);

- pedagogical (lack of culture of behavior legal, moral, civil, aesthetic, economic, labor);

- socio-pedagogical (lack of conscious parenting, family values in society, a positive model of family life on the basis of gender equality, family education based on the rights of the child);

- legal (attitude to violence as an internal family problem, not as a negative social phenomenon, to family members - as property; lack of legal awareness);

- political (tendency to gender stereotypes; insufficient priority of family and gender equality issues; attention to motherhood and childhood, not to the family in general; lack of attention to parenthood, men);

- $\quad$ socio-medical (lack of reproductive culture in the population, responsible parenthood, the system of family doctors; alcoholism, drug addiction, aggression, etc.);

- physiological and medical (disorders of hormonal background, metabolism, speed of reactions; taking stimulant drugs; diseases of the nervous system, etc.).

In our opinion, the above list of reasons that contribute to the commission of domestic violence is quite detailed, not all of them are reflected in the realities of domestic violence with the participation of the elderly. We consider it expedient in the field of domestic violence studied by us to single out only those that lead to the commission of domestic violence with the participation of the elderly, including: economic (low standard of living, greed for inheritance, etc.); medical (presence of age-related health disorder, chronic diseases, etc.); psychological (propensity to drink alcohol, lack of stereotypes of behavior in the family, etc.); legal (illusions about avoidance of punishment for the crime, ignorance or disbelief in the support of the state and others).

\section{Conclusions}

Summarizing the above, we can conclude that the problem of domestic violence against the elderly is quite relevant both in Ukraine and abroad. It requires detailed research on the warning and 


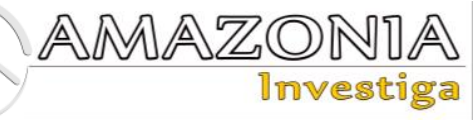

prevention of such violence, the formation of scientific and practical recommendations for the investigation of criminal offenses involving the elderly and committed against them.

The elderly people now need close attention to themselves: from the public, which can be the initiator of preventive work; by the government, which regulates state policy and is a guarantor of providing support to those who need it; on the part of law enforcement agencies, which must promptly respond to the facts of domestic violence and take immediate measures to stop them; by health care institutions, to identify the facts of illegal actions against the elderly and provide them with the necessary assistance; by social services to provide assistance to persons in need in the form of counseling, asylum, etc.

The facts of domestic violence against this age group are quite common, but they are often hidden. The impossibility of an objective assessment of the scale of this issue is due to the lack of official statistics.

Statistics on victims of domestic violence and offenders play an important role in informing those responsible and citizens about the seriousness of the problem. In this regard, we consider it appropriate to emphasize the necessity for statistical reporting in Ukraine, reflecting the categories of persons who have become victims of domestic violence.

Duting the analysis of criminal proceedings concerning the commission of murders, which were preceded by systematic violence of various kinds by family members, it was established that there is a need to: 1) ratify the Istanbul Convention; 2) making proposals for amendments to the criminal legislation of Ukraine on the separation of a certain category of murders in connection with the use of domestic violence; 3) development and formation of scientific and practical recommendations for the investigation of this category of murders.

The reasons and conditions that contribute to the commission of domestic violence against the elderly can be classified into the following groups: economic; psychological; legal and medical. Proper awareness of these reasons is the key to effective prevention and counteraction to domestic violence.

Having analyzed the experience of foreign countries and Ukraine in combating domestic violence, it became possible to trace the effectiveness of the fight against the studied phenomena with the help of public organizations. It is emphasized that the proper professional training of employees of specialized bodies (law enforcement, health care institutions, courts) in the warning, prevention and investigation of domestic violence, and especially with the participation of the elderly, plays an important role in this issue.

We suppose that the conditions that lead to domestic violence involving the elderly in Ukraine include: economic (low living standards, greed for inheritance, etc.); medical (the presence of age-related health disorders, chronic diseases, etc.); psychological (propensity to drink alcohol, lack of stereotypes of behavior in the family, etc.); legal (illusions about avoidance of punishment for the crime, ignorance or disbelief in the support of the state and others).

\section{Bibliographic References}

Acierno, R, Hernandez, MA, \& Ananda, B (2009). Prevalence and correlates of emotional, physical, sexual, and financial abuse and potential neglect in the United States: The National Elder Mistreatment Study. American Journal of Public Health, 100(2), 292-297. Retrieved from http://europepmc.org/article/MED/20019303

Acierno, R. (2003) Elder mistreatment: epidemiological assessment methodology. Washington, DC: National Academy of Sciences, pp. 261-302. Retrieved from https://www.researchgate.net/publication/31 2532510_Elder_mistreatment_epidemiologi cal_assessment_methodology

Case no. 388/147/14-к. (Unified register of court decisions of Ukraine, February 26. 2014). Retrieved September 29, 2021, from https://reyestr.court.gov.ua/Review/3733753 1

Case no. 189/1805/16-к. (Unified register of court decisions of Ukraine, May 30, 2017). Retrieved September 29, 2021, from https://reyestr.court.gov.ua/Review/6564830 4

Evsyukova, M.V., Hristova, G.O., \& Shapovalova, O.A. (2011). Judicial proceedings in cases of domestic violence in Ukraine: problems of compliance with international standards and ways to improve. Scientific and practical manual. Kiev: Vaite LLC, 196 s. Retrieved from http://krona.org.ua/library.html?nav_start=5 0 .

Gerasimenko G.V. (2018). Problems of law enforcement response to domestic violence through the prism of public opinion. 
Demography and Social Economy, № 1(32), 43-57

Halai, A. O., Halai, V. O., Holovko, L. O., \& Muranova, V. V. (2014) International experience in preventing and combating domestic violence. Kyiv: KNT. 160 c. Retrieved from https://www.academia.edu/9038174/Міжнар одний_досвід_протидіїдомашньому_нас ильству_2014

Homer, A. C., \& Gilleard, C., (1990). Abuse of elderly people by their carers. BMJ, 301(6765), 1359-1362. Retrieved from http://europepmc.org/article/MED/2271883

Kharytonov, E., Kharytonova, O., Kharytonova, T., Kolodin, D., \& Tolmachevska, Y. (2019). Human rights as the basic value of the concept of private law in modern Europe. Amazonia Investiga, 8(20), 477-485. Retrieved from https://amazoniainvestiga.info/index.php/am azonia/article/view/177

Kholostova, E.I. (2009). Social gerontology: study guide for students and universities. M: Prosveshenniye, 106 p. Retrieved from http://soc-education.ru/wpcontent/uploads/2017/11/SocRab-c-pogilludmi-Holostova.pdf

Laumann, E.O., Leitsch, S.A., \& Waite, L.J. (2008). Elder mistreatment in the United States: prevalence estimates from a nationally representative study. The Journals of gerontology. Series B, Psychological Sciences and Social Sciences, 63(4). Retrieved from http://europepmc.org/article/MED/18689774 \#R1

Lehenka, M.M. (2017). Foreign experience in combating domestic violence and opportunities Of use in Ukraine. Law and security, № 4 (67), pp. 111-116.

Liga 360 (2011). Council of Europe Convention on Preventing and Combating Violence against Women and Domestic Violence Retrieved from https://ips.ligazakon.net/document/mu11251

Lysenko, Yu. (2017). Socio-pedagogical prevention of violence against the elderly in the information society. Pedagogical sciences: theory, history, innovative technologies, № 8 (72). Pp. 279-289

Minich, R. (2020, July 21). Why Ukraine needs the Istanbul Convention and what it will change. Ukrainian Pravda. Retrieved October 4, 2021, from https://life.pravda.com.ua/society/2020/07/2 $1 / 241713 /$.

Morgay, L. (2018). Pecularities of the work of a social worker with the elderly. Collection of
Scientific Papers of Uman State Pedagogical University, Issue 2, pp. 157-165. Retrieved from

http://znp.udpu.edu.ua/article/view/149234

Movchan, R., Neledva, N., Kalimbet, I., Medentsev, A., \& Nikitina-Dudikova, H. (2021). The behavior of a victim in the field of prevention of sexual violence on the Internet: a psychological aspect. Amazonia Investiga, 10(40), 142-152. Retrieved from https://amazoniainvestiga.info/index.php/am azonia/article/view/1607/1679

Mytnyk, U.M. (2019) Criminal-legal counteraction to domestic violence in some countries of the European Union. Scientific notes of NaUKMA. Legal sciences, Vol 3. Retrieved from http://nbuv.gov.ua/UJRN/NaUKMAun_201 9_3_13

Law of Ukraine No. 1058-IV. On the obligatory state pension insurance, Verkhovna Rada of Ukraine, dated 09.07.2003. Retrieved from https://zakon.rada.gov.ua/laws/show/105815\#Text

Law of Ukraine No. 2229-VIII. On preventing and combating domestic violence, Verkhovna Rada of Ukraine, dated 07.12.2017. Retrieved from https://zakon.rada.gov.ua/laws/show/222919\#Text

Law of Ukraine No. 2341-III. The criminal code of Ukraine, Verkhovna Rada of Ukraine. dated 05.04.2001. Retrieved from https://zakon.rada.gov.ua/laws/show/234114\#Text.

Law of Ukraine No. 3721-XII. On the basic principles of social protection of labor veterans and other elderly citizens in Ukraine, Verkhovna Rada of Ukraine, dated 16.12.1993. Retrieved from https://zakon.rada.gov.ua/laws/show/372112\#Text

OMS (2020). FIFA, the European Commission and the World Health Organization launch the \#SafeHome campaign to support people at risk of domestic violence. World Health Organization. Retrieved from https://www.who.int/ru/news/item/26-052020-fifa-european-commission-and-worldhealth-organization-launch-safehomecampaign-to-support-those-at-risk-fromdomestic-violence

Pillemer, K., \& Finkelhor, D. (1988). The Prevalence of Elder Abuse: A Random Sample Survey. The Gerontologist, 28(1), pp. 51-57, Retrieved from https://doi.org/10.1093/geront/28.1.51

Quigg, Z., Butler, N., Passmore, J., Yon, Y., \& Nihlén, A. (2020). Sustainable Development 
Goals. World Health Organization. Retrieved from https://www.euro.who.int/en/healthtopics/health-policy/sustainabledevelopment-goals.

Serebryakova, T., Koneva, I., Ladykova, O., Begantsova, I., Kostina, O., Yegorova, T., \& Fomina, N. (2019). Manipulation as a form of manifestation of violence in the family: an empirical approach to considering the problem. Amazonia Investiga, 8(21), 767-775. Retrieved from https://amazoniainvestiga.info/index.php/am azonia/article/view/165

Volodina, O.O., \& Malinovskaya, T.M. (2020). Prevention of domestic violence against the elderly. Law and security, pp. 81-85 